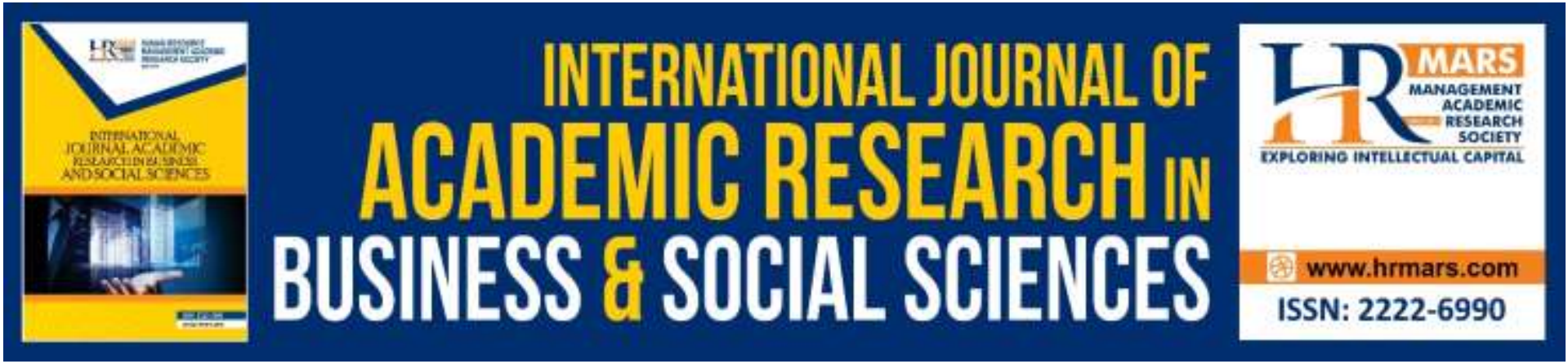

\title{
Corporate Performance: An Indicator for Corporate Future Direction from the Eyes or Top Management
}

Law Bi Rong, Tan Owee Kowang, Ong Choon Hee, Goh Chin Fei, Lim Kim Yew

To Link this Article: http://dx.doi.org/10.6007/IJARBSS/v9-i9/6387

DOI: $10.6007 /$ IJARBSS/v9-i9/6387

Received: 28 July 2019, Revised: 16 August 2019, Accepted: 30 August 2019

Published Online: 04 September 2019

In-Text Citation: (Rong, Kowang, Hee, Fei, \& Yew, 2019)

To Cite this Article: Rong, L. B., Kowang, T. O., Hee, O. C., Fei, G. C., \& Yew, L. K. (2019). Corporate Performance: An Indicator for Corporate Future Direction from the Eyes or Top Management. International Journal of Academic Research in Business and Social Sciences, 9(9), 1000-1016.

Copyright: @ 2019 The Author(s)

Published by Human Resource Management Academic Research Society (www.hrmars.com)

This article is published under the Creative Commons Attribution (CC BY 4.0) license. Anyone may reproduce, distribute, translate and create derivative works of this article (for both commercial and non-commercial purposes), subject to full attribution to the original publication and authors. The full terms of this license may be seen at: http://creativecommons.org/licences/by/4.0/legalcode

Vol. 9, No. 9, 2019, Pg. $1000-1016$

http://hrmars.com/index.php/pages/detail/IJARBSS

JOURNAL HOMEPAGE

Full Terms \& Conditions of access and use can be found at http://hrmars.com/index.php/pages/detail/publication-ethics 


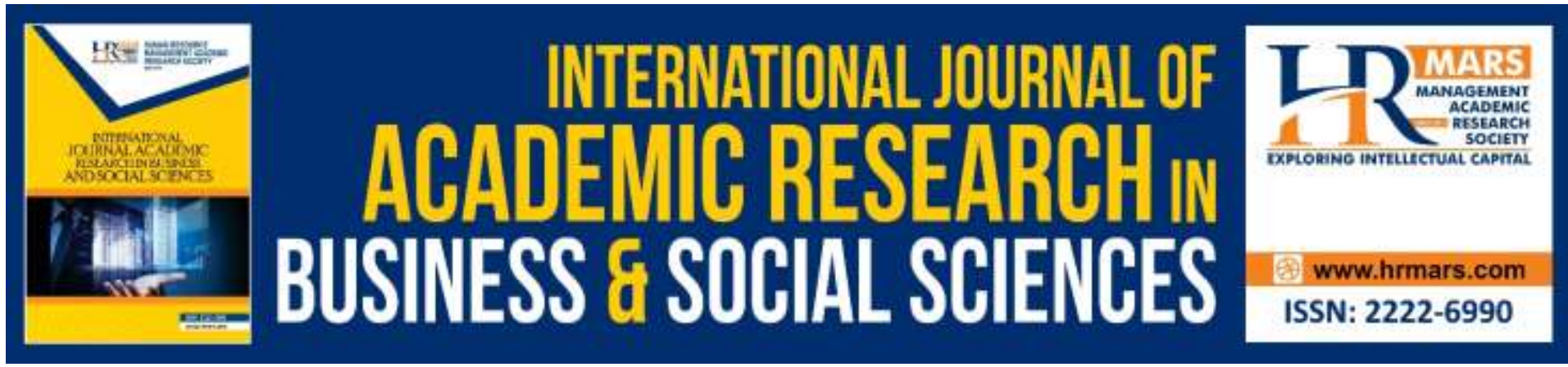

\title{
Corporate Performance: An Indicator for Corporate Future Direction from the Eyes or Top Management
}

\author{
${ }^{1}$ Law Bi Rong, ${ }^{1 *}$ Tan Owee Kowang, ${ }^{1}$ Ong Choon Hee, ${ }^{1}$ Goh \\ Chin Fei, ${ }^{2}$ Lim Kim Yew \\ ${ }^{1}$ Azman Hashim International Business School, Universiti Teknologi Malaysia, Johor, \\ Malaysia. \\ ${ }^{2}$ INTI International University, Nilai, Malaysia \\ Email:oktan@utm.my
}

\begin{abstract}
Corporate Performance measure and assess how good an organisation executes compare its goals and objectives. Typically, corporate performance was used as a tool to gauge department or functional role efficiency, identify which is performing well and which isn't, determine on workforce compensation and plan for productivity improvement. The ability to measure performance follow by implementing improvement change is a highly appreciated managerial skill, hence proper and comprehensive understanding of corporate performance will gives ideas and priorities for top management to make strategic move for corporate future direction. This paper aimed to evaluate how prior researches had been dealing with corporate performance in recent years taking in account different role and departmental perspective. This paper examines over 20 years of research on corporate performance from various perspective of organisation role using a systematic review. The key findings indicated that Operational Performance is always important when it comes to post Research and Development role, such as product development, quality management, supply chain management and green supply chain. Economic Performance, Accounting Performance and Financial Performance are also important as they have shared almost similar measure by prior researchers. This is followed by Environmental Performance and Social Performance or Market Performance which emerged as an important dimension. The study pinpoints key performance factors that could be practically used as an indicator for top management, leading to corporate future direction in current high volatility global economy, worth fully for further study.

Keywords: Corporate Performance, Firm Performance, Top Management, Green Supply Chain, Supply Chain Management, Quality Management, Product Development, Design for Environment, Innovation.
\end{abstract}




\section{Introduction}

Performance can be defined as the accomplishment of a given task measured against pre-set known standards of accuracy, completeness, cost and speed. Performance may be understood as "the potential for future successful implementation of actions in order to reach the objectives and targets" (Lebas, 1995). Corporate performance illustrate how good an organization, either is a firm, a corporate or a company execute and achieve its objectives or shared purpose. This usually covers a composite assessment including organization important parameters, typically financial, market and shareholder performance. According to David Wade (2001), traditional corporate level performance measures only on financial performance, have failed most corporations. CEOs are looking for a performance measures that offer predictive power and better understanding of each process situation, meanwhile, institutional investors are becoming more concerned with the long-term health and overall performance of the companies in which they have invested. (Galdeano, Ahmed, Fati, Rehan, \& Ahmed, 2019).

Corporate performance can be hard to manage due to it is only partially controlled by managers on the internal performance while others will be assessed by its markets on external performance. New products or services can be introduced to the market on a regular basis, but customer preferences and spending behavior can be easily changed, affected by fashions, economics, political conditions and lots of variables across time (Leseure, 2010). Due to this fact, it is difficult to align internal performance with external performance in this dynamic and turbulent market. However, there is lack of study to incorporate both of them in Corporate Performance. There is another problem on corporate performance measurement in operations, which has been relying too much on accounting-driven to achieve financial performance, which is usually short term. Accounting system however were developed to standardize for external reporting and internal control, but it focus mainly on financial statistics, such as sales, profits, cost of sales and etc. When this is slowly accepted as performance measurement for manufacturing and operation, it led to poor decisions making, because this system measured the wrong things in the wrong way, and motivated people to do the wrong things as mentioned by Steve Brown et al. (2001). There is a need of research to explore performance factors which enable different stakeholders to work together closely to support long term organizational competitiveness and performance. (Ahmed, Majid, Zin, Phulpoto, \& Umrani, 2016).

In the current literature of "corporate performance" or "firm performance", these two terms have been used widely with a variety of measurements but lack of research to explore and propose a comprehensive and specific indicator for top level management such as CEO or Managing Director (Leseure, 2010; Steve Brown et al., 2001; David Wade (2001). In order to explore into this matter, researcher aims to explores corporate performance from various stakeholders' perspective as well as different functionality in corporate, follow by suggestion of key performance measures for top management, with the ultimate aim to understand corporate current achievement as well as potential future success. 


\section{Literature Review}

The study started with the most common operation activities from lower stream, such as in supply chain management, purchasing and supply management and quality management. For supply chain management, researcher has further look into "Green Supply Chain" as well as "Environmentally Sustainable Supply Chain" following by current global nation and organization focus on green and environment sustainable.

\section{Green Supply Chain Perspective}

Literature based on meta-analysis of empirical evidences in Asian emerging economies for the relationship between "Green Supply Chain" management and performance was done by Geng, Mansouri et al. (2016). Rapid industrialisation and modernization around us have caused issue such as toxic pollutions, chemical spills, greenhouse gases emissions and others, which lead to negative impacts on our environment in recent years (Peng and Lin 2008). Based on Abdulrahman, Gunasekaran et al. (2014), Lo (2014), Mitra and Datta (2014), the Green Supply Chain Management practices might lead to desirable corporate performance and there is a clear academic need for this research. Table 1.0 summarize dimensions developed to compare and contrast specific effects of management practices on firm performance following systematic review of the literature on corporate performance measurement as below:

Table 1.0 Corporate Performance Dimensions from Green Supply Chain Perspective

\begin{tabular}{lll}
\hline Dimensions & Measures & Literature review \\
\hline Economic Performance & (In general refer to & Abdullah, Ab Halim et al. \\
& profitability) & (2014) \\
& Objective/Growth in sales. & Chan, He et al. (2012) \\
& Objective/Growth in profit. & Kuei, Chow et al. (2013) \\
& Objective/Growth in market & Lee, Rha et al. (2013) \\
& share. & \\
Environmental & Saving energy and reducing & Chiou, Chan et al. (2011) \\
Performance & waste. & Lee (2012) \\
& Pollution. & Rao (2002) \\
& Emissions. & Zhu, Sarkis et al. (2005) \\
Operational Performance & Scrap rate. & Zhu, Sarkis et al. (2012) \\
& Delivery time. & Lai and Wong (2012) \\
& Inventory levels. & Dou, Zhu et al. (2013) \\
& Capacity utilization. & Wong, Lai et al. (2009) \\
& Product and company image. & Zailani, Jeyaraman et al. \\
Social Performance & Employee health and safety. & (2012) \\
& Customer loyalty and & Ashby, Leat et al. (2012) \\
& satisfaction. & \\
\hline
\end{tabular}

Supply Chain Management Perspective 
On the other prior study based on the relationship between "Environmentally Sustainable Supply Chain" management practice and firm performance done by (Golicic and Smith 2013), mentioned that firm performance, which in general used to mean the successful execution and accomplishment of work, has also been operationalized in various ways. Three dimensions of firm performance that are most frequently used in business as well as supply chain research were summarise as accounting based, operational based and market based as shown in below Table 2.0. According to (Gunasekaran and Kobu 2007), (Hult, Ketchun et al. 2008b), (Hult, Ketchun et al. 2008a), (Vachon and Klassen 2008), these three dimensions capture the primary criteria from popular measurement standards such as the balanced scorecard as well as address the primary supply chain stakeholders. These stakeholders include shareholders measure on financial, suppliers who measure on operational, employees who measure on operational, competitors who measure on market and customers who measure on market.

Corporate performance definition has also been further confirmed by Zimmermann and Foerstl (2014) in their study on purchasing and supply management practice with firm performance. This study classified firm performance into the three dimensions most frequently studied in Purchasing and Supply Management and Supply Chain Management research: operational performance, market performance, and accounting performance. (Gunasekaran and Kobu 2007; Vachon and Klassen 2008). This categorization is also consistent with other meta-analytical studies in the field of Supply Chain Management by Golicic and Smith (2013). 
Table 2.0 Corporate Performance Dimensions from Supply Chain Management Perspective

\begin{tabular}{|c|c|c|}
\hline Dimensions & Measures & Literature review \\
\hline Accounting Performance & $\begin{array}{l}\text { (Overall profitability) } \\
\text { Return ratios. } \\
\text { Earnings. } \\
\text { Profit. }\end{array}$ & $\begin{array}{l}\text { Kassinis and Soteriou (2003) } \\
\text { Zhu and Sarkis(2004) } \\
\text { Gonzalez-Benito and Gonzalez- } \\
\text { Benito(2005) } \\
\text { Rao and Holt (2005) } \\
\text { Zhu, Sarkis and Lai(2007) } \\
\text { Jayaram et al. (2008) } \\
\text { Pullman, Maloni and Carter } \\
\text { (2009) } \\
\text { Lopez-Gamero et al.(2010) } \\
\text { Pullman et al. (2010) } \\
\text { Zeng, Meng, Yin,Tam and } \\
\text { Sun(2010) } \\
\text { Paulraj (2011) } \\
\text { Yang et al. (2011) }\end{array}$ \\
\hline Operational Performance & $\begin{array}{l}\text { (Operational efficiency) } \\
\text { Costs. } \\
\text { Quality. } \\
\text { Flexibility. } \\
\text { Speed. } \\
\text { Capacity utilization. }\end{array}$ & $\begin{array}{l}\text { Sroufe (2003) } \\
\text { Gonzalez-Benito and Gonzalez- } \\
\text { Benito(2005) } \\
\text { Vachon and Klassen(2006) } \\
\text { Chung and Tsai(2007) } \\
\text { Zhu et al. (2007) } \\
\text { Peng and Lin (2008) } \\
\text { Skinner, Bryant and Richey } \\
\text { (2008) } \\
\text { Vachon and Klassen (2008) } \\
\text { Wu et al. (2008) } \\
\text { Fraj-Andres et al.(2009) } \\
\text { Pullman et al. (2009) } \\
\text { Olorunniwo and Li(2010) } \\
\text { Pullman et al. (2010) } \\
\text { Yang, Lin, Chan and Sheu (2010) } \\
\text { Chiou et al. (2011) } \\
\text { Large and Thomson(2011) } \\
\text { Golicic and Smith (2013) }\end{array}$ \\
\hline $\begin{array}{l}\text { Market } \\
\text { Performance }\end{array}$ & $\begin{array}{l}\text { (Financial indicators reflecting } \\
\text { market goals) } \\
\text { Market share. } \\
\text { Competitive advantage. } \\
\text { Customer loyalty. } \\
\text { Brand equity. } \\
\text { Customer satisfaction. }\end{array}$ & $\begin{array}{l}\text { Kassinis and Soteriou (2003) } \\
\text { Gonzalez-Benito and Gonzalez- } \\
\text { Benito(2005) } \\
\text { Chen et al. (2006) } \\
\text { Chen (2008) } \\
\text { Peng and Lin (2008) } \\
\text { Fraj-Andres et al.(2009) } \\
\text { Lopez-Gamero et al.(2010) } \\
\text { Pullman et al. (2010) } \\
\text { Zeng et al. (2010) } \\
\text { Yang et al. (2011) } \\
\text { Golicic and Smith (2013) }\end{array}$ \\
\hline
\end{tabular}




\section{Quality Management Perspective}

While in Quality Management context, Nair (2006) highlighted that quality management represents one of the most significant research themes in operations management. An increased of interest level in Quality Management by sectors on economy, such as manufacturing, service, health care, education and government was identified. It is also a widely accepted organizational goal for many companies today (Dean and Bowen 1994). Firm performance was conceptualized differently across studies according to review of literature and summarise in Table 3.0 below. Financial performance, measured in terms of growth in market share, profitability, return on assets was considered in some studies. Meanwhile, other studies considered operational performance measured in terms of product/process quality and inventory and still others have considered customer satisfaction. In some studies a multidimensional operationalization of performance is considered while others considered single performance construct.

Table 3.0 Corporate Performance Dimensions from Quality Management Perspective

\begin{tabular}{|c|c|c|}
\hline Dimensions & Measures & Literature review \\
\hline Financial Performance & $\begin{array}{l}\text { Growth in market share. } \\
\text { Profitability. } \\
\text { Return on assets. }\end{array}$ & $\begin{array}{l}\text { Mohrman, Tenkasi et al. (1995) } \\
\text { Powell (1995) } \\
\text { Hendricks and Singhal (1996) } \\
\text { Hendricks and Singhal (1997) } \\
\text { Chenhall (1997) } \\
\text { Grandzol and Gershon (1997) } \\
\text { Easton and Jarrell (1998) } \\
\text { Das, Handfield et al. (2000) } \\
\text { Wilson and Collier (2000) } \\
\text { Douglas and Judge (2001) } \\
\text { Kaynak (2003) }\end{array}$ \\
\hline Operational Performance & $\begin{array}{l}\text { Product quality. } \\
\text { Process quality. } \\
\text { Inventory performance. } \\
\text { Customer satisfaction. }\end{array}$ & $\begin{array}{l}\text { Flynn, Schroeder et al. (1995) } \\
\text { Choi and Eboch (1998) } \\
\text { Ahire and O'Shaughnessy(1998) } \\
\text { Forza and Flippini (1998) } \\
\text { Dow, Samson et al. 1999) } \\
\text { Samson and Terziovski (1999) } \\
\text { Ho, Duffy et al. (2001) } \\
\text { Kaynak (2003) } \\
\text { Adam Jr., Corbett et al. (1997) } \\
\text { Anderson, Rungtusanatham et } \\
\text { al. (1995) } \\
\text { Rungtusanatham, Forza et al. } \\
\text { (1998) }\end{array}$ \\
\hline
\end{tabular}

Product Development Perspective

Meanwhile, when we look into upper stream of corporate operation activities, it covers product development stage and design stage. According to Ghalayini, Noble et al. (1997), in order to achieve and maintain competitive advantage, corporate must be able to produce high quality and low cost products while increasing variety and reducing production lead time. This is why performance measurement is required to evaluate the success of these processes. Also according to Wang, Lee et al. (2012), for increasing profits and competitiveness, product 
development process is one of an organization's most important processes. Performance measurements are an essential element in planning and controlling organizational activities, such as the product development process (Driva, Pawar et al. 2001). Below Table 4.0 provide a summary of prior research on firm performance which can be understood from indicator and measures selected.

Table 4.0 Corporate Performance Dimensions from Product Development Perspective

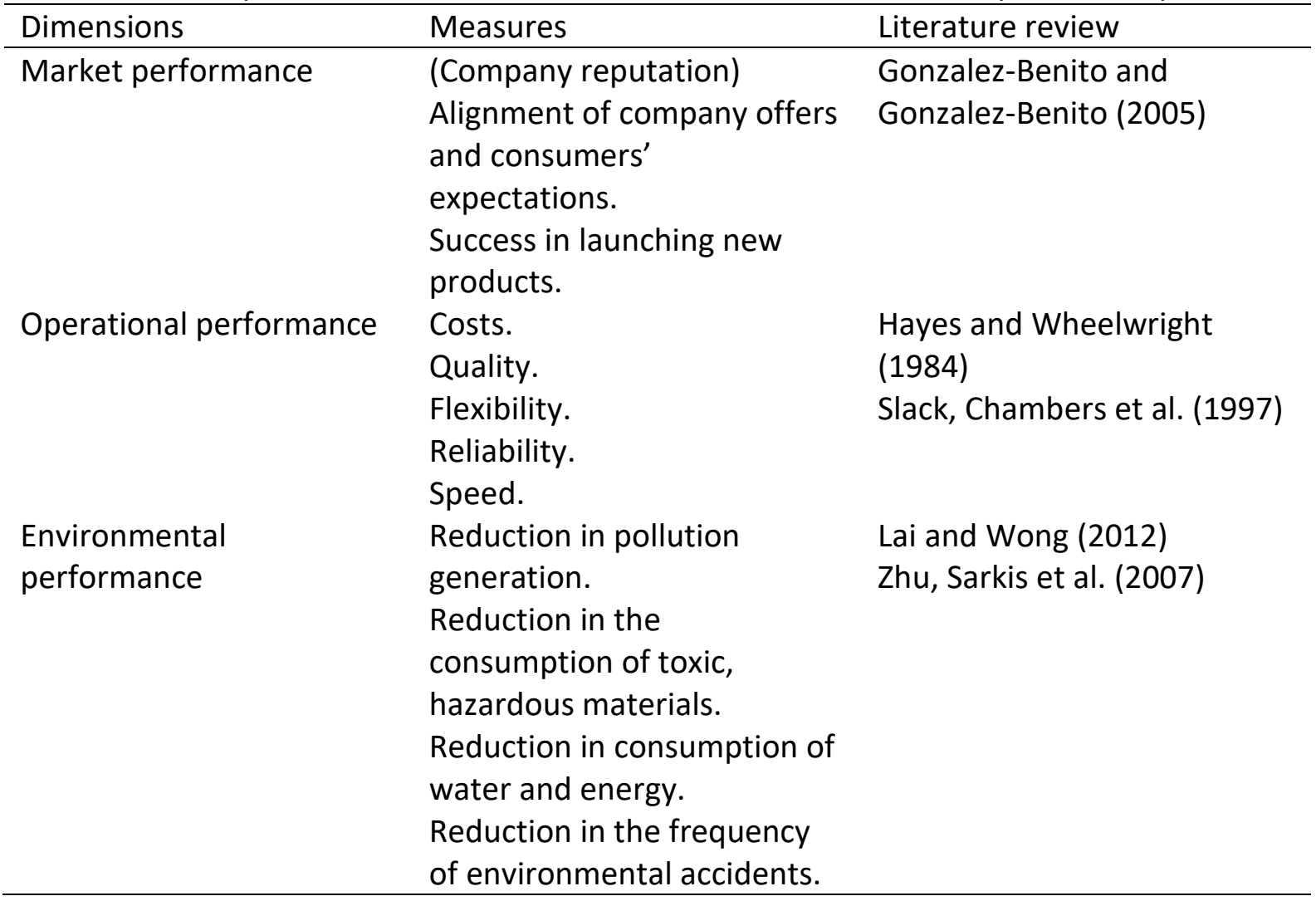

Design for Environment Perspective

According to the Porter hypothesis, strict environmental regulations can induce efficiency and encourage innovations that help improve commercial competitiveness. Since Porter's hypothesis (Porter and Van der Linde 1995) was proposed, the argument that environmental management can generate superior competitive performance for companies by improving their performance and competitiveness has gained strength. Based on Dangelico and Pujari (2010), green products are not sustainable to long term market success, unless they can demonstrate credible environmental.

From a prior study by Jabbour, Jugend et al. (2015) on performance of Brazilian firms used Market performance, Operational performance and Environmental performance as firm performance had proven positive influence of green product development against Firm Performance. According to Pujari, Wright et al. (2003), market performance and ecoperformance indicators need to be understood to ascertain the effectiveness of developing environmentally improved products. Gmelin and Seuring (2014) also mentioned that sustainability aspects have been neglected in the development of new products. However, 
Ellram, Tate et al. (2008) convinced that it is possible to reach environmental sustainability goals while meeting organizational profitability targets and excellence in new product performance. In this sense, it is important to understand the indicators that should be used to assess the firm performance and measures of environmental performance.

In the design context, Jackson, Gopalakrishna-Remani et al. (2016) examining impact of Design for Environment on firm performance indicated environmental and economic performance have a strategic role to play. Melnyk, Sroufe et al. (2003) has also use the same multi-faceted approach to firm performance evaluation accepted by other researchers. Table 5.0 below provides details of measures used on environmental performance and economic performance for study in design for environment.

Firm environmental performance chosen is based on the environmental performance perspective identified by Angell and Klassen (1999), environmental performance involves measurable improvement over time in pollution and waste minimization, reduced consumption of materials and energy, and re-use and/or recycling of products, components, materials, and packaging. For measurement on firm economic performance as distinguished from firm environmental performance, focus was set on reduction of pollutants and wastage of resources, where firm economic performance can be improved through a reduction of costs resulting from environmental initiatives according to Jackson, Gopalakrishna-Remani et al. (2016).

Table 5.0 Corporate Performance Dimensions from Design for Environment Perspective

\begin{tabular}{|c|c|c|}
\hline Dimensions & Measures & Literature review \\
\hline $\begin{array}{l}\text { Environmental } \\
\text { performance }\end{array}$ & $\begin{array}{l}\text { Improvement over time in } \\
\text { pollution. } \\
\text { Waste minimization. } \\
\text { Reduced consumption of } \\
\text { materials and energy. } \\
\text { Reuse and recycling of } \\
\text { products/components. } \\
\text { Reuse and recycling of } \\
\text { materials/packaging. }\end{array}$ & $\begin{array}{l}\text { Angell and Klassen (1999) } \\
\text { Sherry Avery Jackson, } \\
\text { Venugopal Gopalakrishna- } \\
\text { Remani et al. (2016) }\end{array}$ \\
\hline Economic performance & $\begin{array}{l}\text { Reduced material and energy } \\
\text { cost. } \\
\text { Reduced fees for waste } \\
\text { discharge and treatment. } \\
\text { Reduced environmental } \\
\text { compliance fines. }\end{array}$ & $\begin{array}{l}\text { Sherry Avery Jackson, } \\
\text { Venugopal Gopalakrishna- } \\
\text { Remani et al. (2016) }\end{array}$ \\
\hline
\end{tabular}

Innovation Perspective

Innovation in the context of smaller firms has received much interest in studies due to the important role play in economic and technological development especially through SME (Acs 
and Audretsch 1988). Innovation strategy can help corporate adopting innovation in many ways, such as introduction of innovative products, services, processes, or business models developed to attractive customer for opportunities to stand out from competition according to Porter (1980). From a dynamic capabilities perspective, SME can gain great benefit from innovation due to the ability to reconfigure their resource base with flexibility compared to large corporate. However, empirical research on the innovation-performance relationship in SMEs shows controversial results. Rosenbusch, Brinckmann et al. (2011) argued that innovation - firm performance relationship is context dependent which is affected by factors such as age of the firm, type of innovation, and cultural context.

According to Brush and Vanderwerf (1992), Murphy, Trailer et al. (1996), there is no standard on how firm performance construct should be examined in empirical research even though the explanation of performance varies between companies is a core issue in strategic management and entrepreneurship research. So, contrary, researchers use a wide variety of different measure, sometimes without justification. By referring to insights from a metaanalytic review of relationships between performance measures, Rosenbusch, Brinckmann et al. (2011) has focused on studies that measure performance along three dimensions: accounting returns, growth, and stock market performance. Table 6.0 below shown the measure used for these 3 dimensions. In addition, there is evidence that self-reported measures highly correlate with objective measures of performance, which include empirical work that relies on subjective measures based above three dimensions according to Dess and Robinson Jr. (1984). Return-based, growth-based, and subjective performance based assessments are equally used across studies. Stock market-based performance measures are underrepresented which is a result of the focus on SMEs.

Table 6.0 Corporate Performance Dimensions from Innovation Perspective

\begin{tabular}{lll}
\hline Dimensions & Measures & Literature review \\
\hline Accounting returns & $\begin{array}{l}\text { Return on assets, ROA } \\
\text { Return on sales, ROS } \\
\text { Sales growth } \\
\text { Growth }\end{array}$ & Combs, Crook et al. (2005) \\
Stock market phare growth & Combs, Crook et al. (2005) \\
& $\begin{array}{l}\text { Tobin's Q market to book } \\
\text { value }\end{array}$ & Combs, Crook et al. (2005) \\
\hline
\end{tabular}

\section{Research Methodology}

Based on the purpose of our study, a systematic review has been executed. According to Geyskens, Krishnam, Steenkamp and Cunha (2009), the best approach to study our hypotheses is by quantitative synthesis of research findings across a large number of studies. This approach combines effects of multiple independent studies, which can provide stronger conclusions compare to those from single study (Hunter and Schmidt, 1990). As mentioned previously, there are a number of research papers and a few meta-analyses on firm performance exist, but they are particularly referred to specific perspective job functions. The results of this analysis should determine an overall relationship between different job 
functions against corporate performance and find dimensions, measures or other factors that explain differences within the studies.

\section{Result}

This study examines over 20 years of research on corporate performance from various perspective of organization role using a systematic review. The study covers corporate functions from lower stream in green supply chain, supply chain management, quality management and move forward to upper stream on product development, design for environment and innovation. The analysis results are summarized in Table 7.0. Abbreviation used in below summary table includes "Mgt." for management, "Dev." for development and "Env." for Environment.

Table 7.0 Summary of Corporate Performance Dimensions

\begin{tabular}{|c|c|c|c|c|c|c|}
\hline $\begin{array}{l}\text { Dimensions for } \\
\text { Corporate/ } \\
\text { Firm Performance }\end{array}$ & $\begin{array}{c}\text { Green } \\
\text { Suppl } \\
y \\
\text { Chain }\end{array}$ & $\begin{array}{l}\text { Suppl } \\
\text { y } \\
\text { Chain } \\
\text { Mgt. }\end{array}$ & $\begin{array}{l}\text { Qualit } \\
\text { y Mgt }\end{array}$ & $\begin{array}{l}\text { Produc } \\
\text { t Dev. }\end{array}$ & $\begin{array}{l}\text { Desig } \\
\mathrm{n} \text { for } \\
\text { Env. }\end{array}$ & $\begin{array}{l}\text { Innov } \\
\text { ation }\end{array}$ \\
\hline Economic Performance & $\mathrm{Y}$ & - & - & - & $Y$ & - \\
\hline Environmental & Y & - & - & Y & Y & - \\
\hline Operational Performance & $Y$ & Y & $Y$ & Y & - & - \\
\hline Social Performance & $Y$ & - & - & - & - & - \\
\hline Accounting Performance & - & Y & - & - & - & Y \\
\hline Market Performance & - & Y & - & Y & - & - \\
\hline Financial Performance & - & Y & Y & - & - & - \\
\hline Growth Performance & - & - & - & - & - & Y \\
\hline Stock Market Performance & - & - & - & - & - & $\mathrm{y}$ \\
\hline
\end{tabular}

\section{Discussion and Conclusion}

Based on Table 7.0 findings from the research, researcher synthesizes some opinions and ideas with respect to Corporate Performance Dimensions from different functions and perspectives.

First of all, Operational Performance was proven to be one of the key performances dimension, this can be easily noticed as operation management is always the core areas for most of the firm or corporate as identified by prior researchers. Although some researcher argue that design management and innovation management might not be part of corporate operations, however they are contributing towards design and process improvement with new product, new feature or new technology to company. Hence, design management and innovation management own exclusive operation or process, which should also be considered as a part of the corporate's operations.

Secondly, after detail study by research into understanding economic performance, accounting performance and financial performance used by previous research, there is a very significant term which covers most of them a profitability or growth in business, market or shares. Thus, research would propose to group these three dimensions although different description and almost similar in term on measures used under economic performance. This 
is based on prior researcher to economic performance to cover a wider aspect such as cost savings and resources usage reduction, such as energy or waste.

Thirdly, for environmental performance, it can be seen as a growing key performance for corporate based on recent research paper, where "green", "environmental" and "sustainable" term is often used. In addition with the global and environmental awareness growth internationally, this performance dimension should not be excluded from corporate performance.

Fourthly, there are some common measures between Social Performance and Market Performance, which both discussed about company image or reputation and customer loyalty and satisfaction. Researcher would recommend Social Performance as a common dimension to cover Market Performance as well. The other reason would be some part of Market Performance, such as market share, market growth specifically financial indicators were already decided to be covered under economic performance.

Finally, the other two dimensions were not considered by researcher, one of them is Stock Market Performance, due to there is a wide range of firm or corporate, especially SMEs were not listed in stock market. Also, stock market performance is influenced by a lot of factors out of corporate or industry aspect, such as political, global and foreign affairs. The other dimension not included by research as an exclusion dimension is Growth Performance, which researcher believes this is a generic term which should have been covered in other selected dimensions, such as operational performance growth, economic performance growth, environmental performance growth and social performance growth. As long as the specific measures of dimensions can be quantified and comparable between two different time points, a positive or negative growth can be easily identified.

\section{Conclusion}

This paper aimed to evaluate how prior researches had been dealing with corporate performance in recent years taking in account different role and departmental perspective. The first purpose was achieved with finding from the research reveals the key corporate performance dimensions suggested by prior researchers. The key findings indicated that Operational Performance is always important, Economic Performance, Accounting Performance and Financial Performance are also important as they have shared almost similar measures, followed by Environmental Performance and Social Performance or Market Performance which emerged as an important dimension in recent studies. Our results indicated a strong relationship between these dimensions and significant impacts on corporate performance. Hence, the second purpose of this study was met where it pinpoints the key performance factors and compiles a corporate performance measure that which could be practically used as corporate future direction indicator by top management. In closing, our objectives for this research have been achieved. Despite these findings, we hope to trigger more studies on this area as we believe that the identified dimensions are a strong indicator of a variety of different industries, yet we do not want to limit to them. More research can be carried out to uncover other moderators and illustrating how these performance measures affects corporate future direction even more clearly in future extensions of this research. 


\section{Acknowledgements}

Authors wish to acknowledge the Malaysian Ministry of Higher Education and Universiti Teknologi Malaysia under the Research Grant (Vote No. 18H59) for sponsoring this publication.

\section{References}

Abdullah, N., Halim A. N., and Yaakub, N. (2014). Reverse logistics: pressure for adoption and the impact on firm's performance. International Journal of Business \& Society. 15(1), 151-170.

Abdulrahman, M. D., Gunasekaran, A., and Subramanian, N. (2014). Critical barriers in implementing reverse logistics in the Chinese manufacturing sectors. International Journal of Production Economics. 147(B), 460-471.

Acs, Z. J. and Audretsch, D. B. (1988). Innovation in large and small firms: an empirical analysis. American Economic Review. 78(4), 678-690.

Adam, J., Corbett, L. M., Flores, B. E., Harrison, N. J., Lee, T. S., Rho, B. H., Ribera, J., Samson, D., and Westbrook, R. (1997). An international study of quality improvement approach and firm performance. International Journal of Operations and Production Management. (17), 842-873.

Ahire, S. L., and O'Shaughnessy, K. C. (1998). The role of top management commitment in quality management: an empirical analysis of the auto parts industry. International Journal of Quality Science. 3(1), 5-37.

Anderson, J. C., Rungtusanatham, M., Schroeder, R. G. and Devaraj, S. (1995). A path analytic model of a theory of quality management underlying the Deming Management Method: preliminary empirical findings. Decision Sciences. (26), 637-658.

Angell, L. C. and Klassen, R. D. (1999). Integrating environmental issues into the mainstream: An agenda for research in operations management. Journal of Operations Management. 17(5), 575-598.

Ashby, A., Leat, M. and Hudson-Smith, M. (2012). Making connections: a review of supply chain management and sustainability literature. Supply Chain Management: An International Journal. 17(5), 497-516.

Brush, C. G. and Vanderwerf, P. A. (1992). A comparison ofmethods and sources for obtaining estimates of new venture performance. Journal of Business Venturing. 7(2), 157-170.

Chan, R. Y. K., He, H., Chan, H. K. and Wang, Y. C. (2012). Environmental orientation and corporate performance: The mediation mechanism of green supply chain management and moderating effect of competitive intensity. Industrial Marketing Management. 41(4), 621-630.

Chenhall, R. H. (1997). Reliance on manufacturing performance, total quality management and organizational performance. Management Accounting Research. 8, 187-206.

Chiou, T. Y., Chan, H., KLettice, F. and Chung, S. H. (2011). The influence of greening the suppliers and green innovation on environmental performance and competitive advantage in Taiwan. Transportation Research Part E: Logistics and Transportation Review. 47(6), 822-836.

Choi, T. Y. and Eboch, K. (1998). The TQM paradox: relations among TQM practices, plant performance, and customer satisfaction. Journal of Operations Management. 17, 5975. 
Combs, J. G., Crook, T. R. and Shook, C. (2005). The dimensionality of organizational performance and its implications for strategic management research. Research Methodology in Strategy and Management. 259-286.

Dangelico, R. M. and Pujari, D. (2010). Mainstreaming green product innovation: why and how companies integrate environmental sustainability. Journal of Business Ethics. 95(3), 471-486.

Das, A., Handfield, R. B., Calantone, R. J. and Ghosh, S. (2000). A contingent view of quality management-the impact of international competition on quality. Decision Sciences. 31, 649-690.

Wade, D. R. R. (2001). Corporate Performance Management, Butterworth-Heinnemann.

Dean, J. W. and Bowen, D. E. (1994). Management theory and total quality: improving research and practice through theory development. Academy of Management Review. 19(3), 393-418.

Dess, G. G. and Robinson, J. R. B. (1984). Measuring organizational performance in the absence of objective measures: the case of the privately-held firm and conglomerate business unit. Strategic Management Journal. 5(3), 265-273.

Dou, Y., Zhu, Q. and Sarkis, J. (2013). Evaluating Green Supplier Development Programs with a Grey-Analytical Network Process-based Methodology. European Journal of Operational Research. 233(2), 420-431.

Douglas, T. J. and Judge, W. Q. (2001). Total quality management implementation and competitive advantage: the role of structural control and exploration. Academy of Management Journal. 44, 158-169.

Dow, D., Samson, D. and Ford, S. (1999). Exploding the myth: do all quality management practices contribute to superior quality performance? Production and Operations Management. 8, 1-27.

Driva, H., Pawar, K. S. and Menon, U. (2001). Performance evaluation of new product development from a company perspective. Integrated Manufacturing System. 12(5), 368-378.

Easton, G. S. and Jarrell, S. L. (1998). The effects of total quality management on corporate performance: an empirical investigation. Journal of Business 71(2), 253-307.

Ellram, L. M., Tate, W. and Carter, C. R. (2008). Applying 3DCE to environmentally responsible manufacturing practices. Journal of Cleaner Production. 16(15), 1620-1631.

Flynn, B. B., Schroeder, R. G. and Sakakibara, S. (1995). The impact of quality management practices on performance and competitive advantage. Decision Sciences 26, 659-691.

Forza, C., and Flippini, R. (1998). TQM impact on quality conformance and customer satisfaction: a causal model. International Journal of Production Economics. 55, 1-20.

Geyskens, I., Krishnam, R., J., Steenkamp, E. M. and Cunha, P. V. (2009). A Review and Evaluation of Meta-Analysis Practices in Management Research. Journal of Management. 35(2), 393-419.

Ghalayini, A. M., Noble, J. S. and Crowe, T. J. (1997). An integrated dynamic performance measurement system for improving manufacturing competitiveness. International Journal of Production Economics. 48(3), 207-225.

Gmelin, H. and Seuring, S. (2014). Determinants of a sustainable new product development. Journal of Cleaner Production. 69(8), 1-9. 
Golicic, S. L. and Smith, C. D. (2013). A meta-analysis of environmentally sustainable supply chain management practices and firm performance. Journal of Supply Chain Management. 49(2), 78-95.

Gonzalez-Benito, J. and Gonzalez-Benito, O. (2005). Environmental proactivity and business performance: an empirical analysis. Omega. 33(1), 1-15.

Grandzol, J. R. and Gershon, M. (1997). Which TQM practices really matter: an empirical investigation. Quality Management Journal. 4(4), 43-59.

Gunasekaran, A. and Kobu, B. (2007). Performance Measures and Metrics in Logistics and Supply Chain Management: A Review of Recent Literature (1995-2004) for Research and Applications. International Journal of Production Research. 45(12), 2819-2840.

Hayes, R. H., and Wheelwright, S. C. (1984). Restoring Our Competitive Edge: Competing through Manufacturing, Wiley, New York.

Hendricks, K. B. and Singhal, V. R. (1996). Quality awards and the market value of the firm: an empirical investigation. Management Science. 42: 415-436.

Hendricks, K. B. and Singhal, V. R. (1997). Does implementing an effective TQM program actually improve operating performance? Empirical evidence from firms that have won quality awards."Management Science. 43, 1258-1274.

Ho, D. C. K., Duffy, V. G. and Shih, H. M. (2001). Total quality management: an empirical test for mediation effect. International Journal of Production Research. 39, 529-548.

Hult, G. T. M., Ketchun, J. D. J., Adams, G. L. and Mena, J. A. (2008). Supply Chain Orientation and Balanced Scorecard Performance. Journal of Managerial Issues. 20(4), 526-544.

Hunter, J. E. and Schmidt, F. L. (1990). Methods of Meta-Analysis - Correcting Error and Bias in Research Findings. Thousand Oaks, CA., Sage Publications.

Kaynak, H. (2003). The relationship between total quality management practices and their effects on firm performance. Journal of Operations Management. 21, 405-435.

Kuei, C., Chow, W. S., Madu, C. N. and Wu, J. P. (2013). Identifying critical enablers to high performance environmental management: an empirical study of Chinese firms. Journal of Environmental Planning and Management. 56(8), 1152-1179.

Lai, K. and Wong, C. Y. (2012). Green logistics management and performance: Some empirical evidence from Chinese manufacturing exporters. Omega. 40(3), 267-282.

Lebas, M. J. (1995). Performance measurement and performance management. International Journal of Production Economics. 41, 23-35.

Lee, S. M., Kim, S. T. and Choi, D. (2012). Green supply chain management and organizational performance." Industrial Management \& Data Systems. 112(8), 1148-1180.

Lee, S. M., Rha, J. S., Choi, D., and Noh, Y. (2013). Pressures affecting green supply chain performance. Management Decision. 51(8), 14.

Leseure, M. (2010). Key Concepts in Operations Management, SAGE Publications Ltd.

Lo, S. M. (2014). Effects of supply chain position on the motivation and practices of firms going green. International Journal of Operations \& Production Management 34(1): 93-114.

Melnyk, S., Sroufe, R. and Calantone. (2003) R. Assessing the impact of environmental management systems on corporate and environmental performance. Journal of Operations Management. 21(3), 329-351.

Mitra, S. and Datta, P. P. (2014). Adoption of green supply chain management practices and their impact on performance: an exploratory study of Indian manufacturing firms. International Journal of Production Research. 52(7), 2085-2107. 
Mohrman, S. A., Tenkasi, R. V., Lawler, E. E. and Ledford, G. G. (1995). Total quality management: practice and outcomes in the largest US firms. Employee Relations. 17(3), 26-41.

Murphy, G. B., Trailer, J. W. and Hill, R. C. (1996). Measuring performance in entrepreneurship research. Journal of Business Research. 36(1), 15-23.

Nair, A. (2006). Meta-analysis of the relationship between quality management practices and firm performance-implications for quality management theory development. Journal of Operations Management 24: 948-975.

Peng, Y. S. and Lin, S. S. (2008). Local responsiveness pressure, subsidiary resources, green management adoption and subsidiary's performance: Evidence from Taiwanese manufactures. Journal of Business Ethics. 79(1-2), 199-212.

Porter, M. E. and Linde, C. D. V. (1995). Toward a new conception of the environment competitiveness relationship. Journal of Economics Perspectives. 9(4): 97-118.

Powell, T. C. (1995). Total quality management as competitive advantage: a review and empirical study. Strategic Management Journal. 16, 15-37.

Pujari, D., Wright, G. and Peattie, K. (2003). Green and competitive influences on environmental new product development performance. Journal of Business Research. 56(8), 657-671.

Rao, P. (2002). Greening the supply chain: a new initiative in South East Asia. International Journal of Operations \& Production Management. 22(6), 632-655.

Rosenbusch, N., Brinckmann, J., and Bausch, A. (2011). Is innovation always beneficial? A meta-analysis of the relationship between innovation and performance in SMEs. Journal of Business Venturing. 26, 441-457.

Rungtusanatham, M., Forza, C., Filippini, R. and Anderson, J. C. (1998). A replication study of a theory of quality management underlying the Deming method: insights from an Italian context. Journal of Operations Management. (17), 77-95.

Samson, D. and Terziovsk, I. M. (1999). The relationship between total quality management practices and operational performance. Journal of Operations Management. 17, 393409.

Vachon, S. and Klassen, R. D. (2008). Environmental Management and Manufacturing Performance: The Role of Collaboration in the Supply Chain. International Journal of Production Economics. 111(2), 299-315.

Wang, K. J., Lee, Y. H. and Kurniawan, F. (2012). Evaluation criteria of new product development process - a comparison study between Indonesia and Taiwan Industrial Manufacturing Firms. Int. J. Innov. Manag. 16(4).

Wilson, D. D. and Collier, D. A. (2000). An empirical investigation of the Malcolm Baldrige National Quality award causal model. Decision Sciences. 31: 361-390.

Wong, C. W. Lai, Y., K. and Teo, S. H. (2009). Institutional pressures and mindful IT management: The case of a container terminal in China. Information \& Management. 46(8), 434-441.

Zailani, S., Jeyaraman, K., Vengadasan, G. and Premkumar, R. (2012). Sustainable supply chain management (GSCM) in Malaysia: A survey. International Journal of Production Economics. 140(1), 330-340.

Zhu, Q., Sarkis, J. and Geng, Y. (2005). Green supply chain management in China: pressures, practices and performance. International Journal of Operations \& Production Management. 2(5), 449-468. 
Zhu, Q., Sarkis, J. and Lai, K. (2012). Institutional-based antecedents and performance outcomes of internal and external green supply chain management practices. Journal of Purchasing and Supply Management. 19(2), 106-117.

Zhu, Q., Sarkis, J. and Lai, K. H. (2007). Green supply chain management: pressures, practices and performance within the Chinese automobile industry. Journal of Cleaner Production. 15(11), 104-1052.

Zimmermann, F. and Foerstl, K. (2014). A Meta-analysis of the Purchasing and Supply Management Practice - Performance Link. Journal of Supply Chain Management. 50(3), 37-54.

Galdeano, D., Ahmed, U., Fati, M., Rehan, R., \& Ahmed, A. (2019). Financial performance and corporate social responsibility in the banking sector of Bahrain: Can engagement moderate? Management Science Letters, 9(10), 1529-1542.

Ahmed, U., Majid, A. H., Zin, M. L., Phulpoto, W., \& Umrani, W. A. (2016). Role and impact of reward and accountability on training transfer. Business and Economics Journal, 7(1). http://dx.doi.org/10.4172/2151-6219.1000195 